\title{
Człowiek nie-zniewolony. Od hellenistycznych wychowawców stoików do ponowoczesnej orgii pragnień
}

\section{STRESZCZENIE}

Artykuł stanowi próbę zderzenia z sobą ideału człowieka postulowanego przez Epikteta i Marka Aureliusza z ponowoczesną tyranią sukcesu i maniakalno-narcystyczną wizją ludzkiej natury. Wyjściem do rozważań jest stanowisko Petera Sloterdijka, który stwierdził, że w kulturach wysoko rozwiniętych wychowanie i edukacja podlegają wpływom hamującym i pozbawiającym hamulców. Istota ludzka, która budziła przerażenie w okresie hellenistycznym, jako naruszający „hybris” szaleniec, obecnie funkcjonuje jako imagopata, idealny produkt, żyjący w świecie możliwości i zacierania się granic między realnym a wirtualnym.

SŁOWA KLUCZE: homo inhumanus, hybris, stoicyzm, pragnienie, logorea, imagopatia, selfie.

\section{Hybris}

Homo inhumanus oznacza po łacinie chama, człowieka bezczelnego, nieprzestrzegającego podstawowych reguł, grubianina. Peter Sloterdijk (2008) tym terminem określił człowieka pozbawionego hamulców, podkreślając, że w kulturach wysoko rozwiniętych wychowanie i edukacja podlegają wpływom hamującym i pozbawiającym hamulców. Jednocześnie w REguŁACH DLA LUDZKIEGo zWIERzyŃCA zwrócił naszą uwagę na dwa fakty. Po pierwsze, w starożytnym Rzymie, kiedy ten osiągnął apogeum swego rozwoju, książka przegrała z amfiteatrem. Okrucieństwa rzymskich aren, położonych wokół Morza Śródziemnego, ukazywały z całą bezwzględnością istotę ludzką (jako widza) pozbawioną hamulców. Sloterdijk wręcz pisze o swoistej bitwie o człowieka, toczonej od starożytności do czasów współczesnych, wskazując na niezwykle ważną rolę wychowawców jako tych, którzy wzmacniają w człowieku tendencje poskramiające zagrożone przez tendencje przeciwne, które niemiecki filozof i kulturoznawca nazywa tendencjami bestializującymi (a które Freud niewątpliwie by utożsamił z żywiołem Tanatosa). Współczes- 
nym bestialstwem rozpalającym namiętności tłumów są niewątpliwie ociekające krwią, ocierające się o nekromanię i perwersję horrory, sadomasochistyczne, pełne okrucieństwa, poniżania i przemocy produkcje pornograficzne czy obrazy typu „reality show”, w których można ujrzeć na żywo działania brutalnych sprawców, jak i zniszczone czy zbrukane ciała ofiar. Zaś w wymiarze bardziej masowym, czyż nie są przejawem bestialstwa ataki „wirtualne" na wybrane ofiary za pomocą portali społecznościowych (hejty i złośliwe, deprecjonujące komentarze)? Również wystawianie na widok publiczny i poddawanie ocenie przez masowy autorytet opinii publicznej tego, co najbardziej intymne, tego, co dotyczy relacji pomiędzy mężem a żoną, rodzicem a dzieckiem, czyż nie jest jednym z najbardziej atrakcyjnych, niezdrowo ekscytujących przejawów tendencji pozbawiających hamulców? Zdaniem Sloterdijka współczesna szkoła (i to jest tendencja trwająca co najmniej od dwóch, jeśli nie trzech dekad) przegrywa bitwę z telewizją, kinem pełnym przemocy i wszelkimi pozbawiającymi hamulców mediami. I jeśli nie powstanie nowa struktura pielęgnacji i kultywacji, szkoła nie ma w tym starciu najmniejszych szans.

Starożytni Grecy o jednostce pozbawionej hamulców mówili, że padła ofiarą hybris. Warto zauważyć, że w mitach greckich, jak i w tragedii attyckiej, hybris ściąga nieszczęście na bohaterów, ich potomstwo, królestwo, jak i poddanych. To pojęcie, oddawane najczęściej za pomocą terminów pycha, duma, związane było z przekroczeniem naturalnej miary, jaką bogowie wyznaczyli człowiekowi. W tragicznych losach Lajosa, Edypa, Orestesa, Heraklesa czy Iksjona możemy ujrzeć metaforę ludzkiego szaleństwa, szaleństwa istoty skazanej, mocą tęsknoty, na wychodzenie poza naturalny porządek rzeczy, istoty przywiązanej do koła egzystencji, pragnącej i nienasyconej, rozdartej przez wiatry natury, która im bardziej chce się od porządku naturalnego oderwać, tym bardziej pada jego ofiarą. Hybris jest stanem, który osiąga jednostka opętana pragnieniami, nadaktywna, kompulsywna, przekraczająca granice i łamiąca wszelkie tabu. Jerzy Bartkowski w artykule „Hybris jako patologia charyzmy" powołuje się na Arnolda Toynbee'ego, który w ten sposób charakteryzuje hybris: „Jest to autodestrukcyjna siła zawarta w dążeniu do przekraczania granic swoich możliwości w wyniku wzbicia się w nadmierną wiarę w siebie" (za: Bartkowski, 2008, s. 113).

Niezależnie od tworzonych teorii na własny temat istota ludzka jest częścią natury i dychotomiczny podział na naturę i kulturę wydaje się być fikcją. Tym niemniej warto zauważyć, że ludzkie pragnienie dąży do hybris. Powstanie refleksyjnej świadomości jest już hybris. Podobnie jak ludzki popęd seksualny, który wykroczył poza naturalne cykle rui i wyciszenia i staje się nie- 
raz całoroczną obsesją, przymusem popychającym do łamania norm obyczajowych, a nawet ciągnącym ku zbrodni i samobójstwu. Popęd głodu zaś, jak to powszechnie wiadomo nie od dziś, pod wpływem natrętnych myśli i wyobrażeń, przestaje służyć zachowaniu przy życiu organizmu, ale staje się destruktywną deformacją, manifestującą się jako zażeranie problemu czy głodzenie się z powodu problemu stworzonego przez ludzki umysł. Jeśli narodziny świadomości zaburzyły ludzkie życie popędowe i sprawiły, że pragnienia nasze nigdy nie dają się zaspokoić, tylko powodują stany chronicznej tęsknoty i „wiecznego" głodu, wówczas na barki tych, którzy sprawują władzę, wychowują i troszczą się o los przyszłych pokoleń, spada ciężkie brzemię. Nie zawsze do udźwignięcia. Związane jest ono z kształtowaniem ludzkiego sumienia. Ale też samo sumienie narażone bywa na hybris. Sumienie może zaszczuć jednostkę, wprowadzić ją wnieuzasadnione poczucie winy i lęk. Może nawet odszczepić się od indywidualnej psyche i stać się treścią urojeń; omamami i halucynacjami, powracającymi do jednostki z zewnątrz, ścigającymi i niszczącymi obsesjami. Jeśli zaś sumienie się nie rozwinie - człowiek zmierza ku psychopatii.

Uwalniając hybris łatwo można zapomnieć o dynamicznej równowadze pomiędzy możliwościami a ograniczeniami. Obecny system społeczno-polityczny, jak nigdy w historii (coraz mniej nas ograniczają kasty i klasy społeczne), podtrzymuje i sankcjonuje iluzję nieograniczonych ludzkich możliwości i czyni z tej iluzji najwyższą prawdę. Dzieci wbijane w genialność przez rodziców, a potem przez ulegających propagandowej presji niektórych nauczycieli, uczą się sztuki opierania się na urojonym obrazie „ja”, oderwanym od charakteru i ciała. Tyrania sukcesu, maniakalno-narcystyczna wizja siebie, zmuszanie młodych ludzi do tworzenia coraz bardziej absurdalnych i fantastycznych projektów własnego losu i przypisywanie im jednocześnie winy za osobiste niepowodzenia, czyż nie mają wpływu, jeśli weźmiemy również pod uwagę technologiczne przyspieszenie cywilizacyjne, na epidemię zaburzeń depresyjnych? Przecież dopiero gdy uwzględniamy własne ograniczenia (somatyczne, psychiczne, materialne), możemy swemu życiu nadać adekwatną formę, dzięki której chaotyczne impulsy popędowe i wyobrażenia stają się konstruktywną treścią naszego losu.

Odpowiedź na pytanie o zdrowie i normę, które zadaje samej sobie istota już z racji urodzenia chora na śmierć, bywa zainfekowana ideologią (mniej lub bardziej totalną), która oferuje iluzoryczne, ale w mniemaniu zwolenników nieprzepuszczalne, granice pomiędzy normalnym a patologicznym, racjonalnym a szalonym. Jednostka opętana przez ideał zdrowia i normy łatwo może wpaść w sidła samowyzysku i katorżniczej samodyscypliny, co prowadzi do 
znęcania się nad własnym ciałem i umysłem, i - paradoksalnie - do spotęgowania choroby, od której pragnęło się uciec. Jacek Sieradzan, religioznawca i filozof, który od dwóch dekad zajmuje się tematem szaleństwa, pokazuje na przykładzie doświadczeń religijnych, teorii naukowych i diagnoz psychiatrycznych, stawianych również zbrodniarzom wojennym i mordercom czasów pokoju, płynność granic między zdrowiem psychicznym i szaleństwem. W końcu dochodzi do wniosku, że „[...] ani człowiek zdrowy psychicznie, ani normalny - nie istnieją" (Sieradzan, 2014, s. 38). Sieradzan zauważa, że ludzi normalnych nawet nie znajdziemy na poziomie fizjologicznym, nie mówiąc już o poziomach psychicznym czy społecznym. By wzmocnić swą tezę autor przytacza jako przykład badania fizjologa i biochemika Rogera J. Williamsa, który ukazał, że zaledwie sześciu na tysiąc badanych nie wykazuje odchyleń od normy podczas porównania „stu nieskorelowanych ze sobą cech". Wystarczy zwiększyć liczbę kategorii badawczych, by okazało się, że każdy z badanych jest nienormalny. Gdzie zatem możemy spotkać ideał człowieka w pełni zdrowego, przede wszystkim psychicznie, jeśli nie w mitach, w baśniach, w podaniach czy w zmitologizowanej przeszłości bohaterów już martwych? W XXI wieku jest zasadnym, by zapytać: mózg, którego z żyjących ludzi zostałby uznany za organ najbliższy ideału? Prezydenta USA, oligarchy rosyjskiego, mnicha buddyjskiego czy chrześcijańskiego papieża, lamy tybetańskiego, przeciętnego, ale nadgorliwego pracownika korporacji (co wielce prawdopodobne), działaczki feministycznej, profesora ekonomii, prawa? Jeśli zaś założymy wielość ideałów (idealnych mózgów?!), to ile wzorców tych idealnych organów ma być? Jest to pytanie, na które każda odpowiedź będzie obarczona dużym ryzykiem kompromitacji, a jedyne, co odpowiadający sobie uświadomi, to własne ograniczenia światopoglądowe. Odpowiedzi na pytania o to, jak mamy żyć, ku czemu dążyć, nasi przodkowie (przede wszystkim mityczni) poszukiwali u mędrców. A jak twierdzi, i słusznie, Sloterdijk: „Bez ideału mędrca piecza człowieka nad człowiekiem pozostaje daremną namiętnością" (Sloterdijk, 2008, s. 61). I jak sam zauważa:

[d]wa i pół tysiąca lat po Platonie wydaje się, jakby nie tylko bogowie, lecz także mędrcy opuścili świat i pozostawili nas samych z brakiem mądrości i naszą połowiczną wiedzą o wszystkim. W miejsce mędrców pozostały nam ich pisma, w surowym blasku i rosnącej ciemności, ciągle jeszcze obecne, w mniej czy bardziej przystępnych edycjach, ciągle jeszcze można by je czytać, gdyby tylko wiedzieć, po co właściwie je otwierać (Sloterdijk, 2008, s. 60).

Ostatnie słowa cytatu wskazują na to, że Sloterdijk (w roku 1999) wieszczył „niebezpieczny koniec humanizmu jako utopii formowania człowieka przez 
pismo i poprzez lekturę, uczącą cierpliwości oraz wychowującą do powściągliwości i do niezatykania uszu" (Sloterdijk, 2008, s. 61).

W przypadku idealnego konsumenta cierpliwość nie jest wskazana, jeszcze mniej wskazana jest powściągliwość, a już zupełnie przeciwwskazana refleksyjność. Idealny wytwór propagandy sukcesu powinien być, niczym hipomaniak, zawsze zadowolony, nie powinien żywić żadnych wątpliwości, jeśli chodzi o cel życia, który jest oparty na dążeniu do bogacenia się i zdobywaniu wszelkich oznak prestiżu (od dyplomów, certyfikatów po podkreślające status przedmioty materialne). Niepohamowany, egoistyczny i nienasycony pęd ku widmu kariery i spełnienia może jednak prowadzić na manowce, ku uzależnieniom, zaburzeniom psychicznym i samobójstwu. Dlatego też zignorujemy wątpliwość Sloterdijka i, by doświadczyć, czym jest zaklęta, przekraczająca otchłanie czasu mowa nieobecnych, otworzymy dwie książki. W pierwszej z nich zetkniemy się z naukami Epikteta (spisanymi przez jego ucznia Arrianusa). Druga jest podręcznikiem pisanym samemu sobie przez cesarza Marka Aureliusza i jest to, prawdopodobnie, pierwsza publikacja na Zachodzie poświęcona trudnej sztuce samowychowania.

Epiktet, grecki niewolnik, który dzięki nawróceniu swego pana na stoickie zasady odzyskał status wolnego człowieka, udziela nam następującej rady:

Z wszystkich rzeczy jedne są od nas zależne, drugie zaś niezależne. Zależne są od nas: sądy, popędy, pragnienia, odrazy i jednym słowem - to wszystko, co jest naszym dziełem. Niezależne natomiast są od nas: ciało, mienie, sława, godności i jednym słowem - to wszystko, co nie jest naszym dziełem. I dlatego te rzeczy, które od nas zależą, z natury są wolne i nie podlegają żadnym zakazom ani przeszkodom, te natomiast, które od nas nie zależą, nie przedstawiają żadnej wartości, spełniają służebną rolę i stanowią cudzą własność. Pamiętaj zatem, że jeśli rzeczy służebne z natury zaczynasz uważać za wolne, a cudze za własne, sam się zaprzęgniesz w niewolę, będziesz rozwodził skargi i żale, doznawał niepokoju, miotał złorzeczenia zarówno na bogów, jak i na ludzi. Jeżeli jednak to tylko, co twoje, uważać będziesz za swoją własność, i przeciwnie - to, co jest cudzą własnością - za przynależne, jak jest w rzeczywistości, do kogoś innego, wtedy nikt nigdy nie będzie na ciebie wywierał przymusu, nikt nie będzie sprawiał ci przeszkód, ani ty sam nie będziesz nikomu złorzeczył, nikogo oskarżał, niczego zgoła czynił wbrew swojej woli, nikt nie wyrządzi ci krzywdy, w nikim nie będziesz miał wroga, bo też i niczego nie doznasz, co by rzeczywiście szkodliwe było dla ciebie (zob. Epiktet, 1961, s. 455).

Według stoików szaleństwo ludzkie polega zatem na pomieszaniu porządków, na pragnieniu, by rzeczy niezależne od nas, stały się zależne, a to, co do mnie nie należy, stało się moje (włącznie z cechami charakteru, urodą fizyczną, zdrowiem, przychylnością autorytetu etc.). W tym pogrążaniu się w szaleństwie, jak i w próbach wyzwolenia się z więzów szaleństwa, olbrzy- 
mią rolę, jakże przy tym ambiwalentną, odgrywa wyobraźnia. Jednak niewielu z nas, paradoksalnie bojąc się posądzenia o szaleństwo, potrafi z własnymi wyobrażeniami wchodzić w dialog. A ta umiejętność jest niezbędna na ścieżce prowadzącej ku pełni psychicznej i spełnieniu, która nie tylko polega na narcystycznym eksplorowaniu rzeczywistości wewnętrznej i zachwycie nad własnym 'ja', lecz również inicjuje nas w ludzką kulturę. Oczywiście możemy wewnętrzne obrazy biernie obserwować, aż rozpłyną się w przestrzeni, ukazując swą "pustą" naturę; możemy z nimi prowadzić dysputy i czuć ich obecność. Jednak kiedy naszym wyobrażeniom towarzyszy silne napięcie emocjonalne, wtedy warto, podobnie jak to czynił cesarz Marek Aureliusz, którego życie nie rozpieszczało, skorzystać z ćwiczenia zalecanego przez Epikteta:

Starajże się tedy każdemu gwałtownemu wyobrażeniu natychmiast przeciwdziałać, tak mówiąc: 'Jesteś tylko wyobrażeniem, czczą marą rzeczy, którą przedstawiasz. Następnie zbadaj owo wyobrażenie i oceń jego wartość wedle takich prawideł, jakie posiadasz, a przede wszystkim i nade wszystko wedle tego prawidła, czy przedstawia ono rzeczy od nas zależne, czy niezależne. I jeśli przedstawia rzecz jakąś, która nie jest od nas zależna, z miejsca wypowiadaj swe zdanie: 'Nic a nic, mnie to nie obchodzi!"” [...] Pamiętaj o tym, że pragnienie mami cię obietnicą zdobycia dobra, którego pożądasz, a odraza mami cię obietnicą zła, przed którym się wzdrygasz, oraz że ten, kto w pragnieniu doznaje zawodu, jest nieszczęśliwy, a ten, kto w odrazie ponosi porażkę - godny politowania. Jeżeli zatem tego tylko unikasz, co zgodnie ze swą naturą jest w twojej mocy, nie doświadczysz zgoła niczego, do czego czujesz odrazę. Jeżeli jednak unikasz choroby, śmierci albo ubóstwa, doznasz bolesnego zawodu. (Epiktet, 1961, s. 456).

W wielu programach telewizyjnych, na wielu stronach internetowych, w publikacjach $\mathrm{z}$ dziedziny nauk ekonomicznych, prawniczych, a nawet społecznych i humanistycznych, w wielu podręcznikach szkolnych, w literaturze popularnonaukowej dotyczącej zdrowia, szczęścia, wychowania, pielęgnowania przyjaźni czy pomnażania pieniędzy odnajdziemy specyficzne doniesienia $\mathrm{z}$ frontu. Czyż nie jesteśmy wciąż namawiani do walki z czymś, na co nie mamy wpływu, z kimś, kto jest poza zasięgiem naszych możliwości, a nawet jest czystą abstrakcją? Bombardowani jesteśmy przez słowa i obrazy, od zewnątrz i od wewnątrz, przekazujące relacje $\mathrm{z}$ walk z samym sobą, ze swoim ciałem i swoimi skłonnościami. Walczymy, zwyciężamy i jesteśmy pokonywani zmagając się z rakiem, schizofrenią, ze wszelkimi ułomnościami fizjologicznymi i psychicznymi. Mamy walczyć o miłość, o uznanie, o pokój, nawet o orgazm... Błędem jednak jest przeciwieństwo tego słowno-obrazowego militaryzmu. Język pokoju, miłości, współczucia łatwo przeistacza się w cukierkowaty kicz. Jest kreacją myślenia życzeniowego, ponieważ wiąże się 
z przeświadczeniem, że można człowiekowi nakazać coś, co jest niemożliwe, co dotyka naszych emocji i uczuć. Bądź tolerancyjny, kochaj, współczuj, bądź wrażliwy na piękno natury...

Jak pisze Pierre Hadot w swej książce poświęconej stoickim ćwiczeniom duchowym Marka Aureliusza:

Pragnienie i czynna pobudka odzwierciedlają rozdwojenie pojęcia woli; pragnienie to w pewnej mierze wola nieskuteczna, natomiast czynna pobudka (czy skłonność) to wola, której skutkiem jest akt (Hadot, 2004, s. 135).

Zatem pragnienie jest czymś nie do zaspokojenia, ponieważ wiąże się z dążeniem do bycia Całością. Z tym że istota ludzka zazwyczaj nie widzi tego, co jest, ponieważ spostrzega zamiast rzeczywistości cienie własnych pragnień i tęsknot. Można rzec, że współczesny kapitalizm preferuje postawy antystoickie. Zamiast dyscypliny przyzwolenia (prawda ${ }^{1}$, odróżnianie prawdy od fałszu), pragnienia (umiar) i działania (sprawiedliwość) mamy żarłoczny świat niepohamowanych, kształtowanych z zewnątrz wyobrażeń i sądów wartościujących, chciwości (rozniecanie pragnień przez reklamę) i działań, które, jeśli nie zabrania prawo, są dozwolone. Wszelkim działaniom podejmowanym przez człowieka towarzyszy fałszywa obietnica osobistego spełnienia (spełnienie zawsze jest jutro, czyli nigdy) oraz przymus oceniania wszystkiego w kategoriach zysku i strat. Jako że człowiek na drodze do sukcesu korzysta nieraz z mechanizmów obronnych (m.in. racjonalizacji i projekcji), za pomocą których można zredukować lęk i zagłuszyć nieczyste sumienie, stwarza to sytuację, w której wszelkie zasady moralne stają się względne, a przecież z nich wypływają ludzkie dążenia i czyny. Jak to ujął wielki cesarz stoik, Marek Aureliusz:

[...] nic nie jest dobre dla człowieka, co go nie robi sprawiedliwym, rozsądnym, dzielnym, wolnym, i nic złe, co nie stwarza cech sprzecznych z wymienionymi (Marek Aureliusz, 2001, s. 67).

Stoicka dyscyplina przyzwolenia wiąże się z wyobrażeniami, które poddaje się krytycznej obserwacji i osądowi wartościującemu. Chodzi o to, byśmy potrafili odróżnić od siebie obiektywny osąd od naszych subiektywnych dodatków. Ta metoda przypomina zalecenia mistrzów zen, jak również naszego filozofa - wychowawcy, reisty, Tadeusza Kotarbińskiego. Dyscyplina pragnień z kolei odnosi się do świata naszych namiętności, które mają ten-

W znaczeniu greckim (aletheia) jako wolność od nieszczerości w postępowaniu, od obłudy, od zatajania swych myśli i czynów (zob. R. Popowski, 1997, s. 21). Także jako akt bycia nieskrytym oraz akt odkrywania i przejrzystego uświadomienia. 
dencję do przekraczania miary z powodu zbyt wielkiego bądź zbyt nikłego ich natężenia, prowadzącego ku emocjonalnej i uczuciowej oziębłości, branej często za samoopanowanie. Ta dyscyplina nie tylko dotyczy tego, co zazwyczaj z pragnieniem nam się kojarzy, lecz również tego, co nas odraża, co budzi naszą awersję. Jesteśmy nieszczęśliwi, wyłączając zdarzenia losowe, na ogół z dwóch powodów: po pierwsze, że pragniemy rzeczy uważanych przez nas za dobro; po drugie - jak już było wspomniane - pragniemy tego, co od nas niezależne. Wreszcie, według stoickich wychowawców, na dyscyplinę działania składają się działania stosowne, obejmujące zarówno instynkt samozachowawczy, jak i dążenie ku sprawiedliwości i służbę innym.

Stoicy uważali, że istnieją jedynie dobro i zło moralne (a nie fantazmaty ideologiczne na temat dobra i zła), które są podstawą ludzkich działań dokonywanych za pomocą myśli, mowy i czynów. Podobne stanowisko reprezentuje buddyzm, szczególnie zaś buddyzm therawady, gdzie sila (moralność) poprzedza wszelkie inne praktyki, ponieważ bez właściwej moralności żaden postęp duchowy nie jest możliwy (zob. np. U Pandita, 2004, s. 11). O tym, że moralność jest niezależna od religii byli przekonani również Konfucjusz i Immanuel Kant.

Spoglądając w ludzką duszę, nie mówiąc już o duszy utożsamianej z sobą, nagle może ogarnąć nas lęk, wstręt i obrzydzenie do siebie i innych ludzi. Cóż, wówczas warto pójść za kolejną, jakże istotną, radą cesarza Marka Aureliusza: „Wzrastać na tym samym pniu, ale nie wyznawać tych samych zasad” (za: Hadot, 2004, s. 290). Jak wyjaśnia nam Hadot, znakomity francuski filozof, który przywrócił do zbiorowej pamięci dawne terapeutyczne funkcje filozofii starożytnej, Marek Aureliusz niejednokrotnie przeżywał konflikt z powodu głębokiej różnicy pomiędzy wyznawanymi przez siebie stoickimi zasadami a zasadami większości ludzi.

Dwa trudne do pogodzenia obowiązki: obowiązek miłości do ludzi, z którymi tworzymy jedno ciało, jedno drzewo, jedno państwo; ale również obowiązek niedopuszczenia do przyjęcia ich fałszywych wartości i maksym życiowych (Hadot, 2004, s. 290).

Oto istotny dylemat, przed którym stoi, niezależnie od epoki, w jakiej przyszło mu żyć, wychowawca, kiedy uświadomi sobie, że jego idealistyczne dążenia podzielają bardzo nieliczni.

Wedle stoików prawdziwym filozofem-mędrcem jest ten, kto czyni postępy w pracy nad sobą. Zdaniem Epikteta człowiek taki dokonuje postępów dzięki temu, iż „[...] ma się na baczności przed samym sobą, jakby sam sobie był wrogiem w każdej chwili gotowym do ataku" (Epiktet, 1961, , s. 483). Stoicki 
mędrzec, podobnie jak Budda, namawia nas do bycia uważnymi i przytomnymi w każdej chwili naszego życia. Oczywiście wielkim nieporozumieniem wydaje się być interpretacja ideału stoickiego (apatheia) jako drogi ku braku doznań, namiętności i pragnień. Jest wręcz przeciwnie. Jak to ujął Anselm Grün, który zwrócił uwagę na wpływ nauk stoickich na poglądy i praktykę duchową chrześcijańskich Ojców Pustyni: „Apatheia oznacza stan, w którym przestaliśmy być zniewoleni przez namiętności, w którym przestały one mieć nad nami władzę, lecz służą nam, obdarowując nas siłą, która w nich tkwi" (Grün, 1999, s. 84). Warto wciąż powtarzać, że różnica pomiędzy niedoznawaniem a zachowaniem wolności i świadomości przy doświadczaniu intensywnych doznań jest przeogromna, tak jak różnica pomiędzy panowaniem nad sobą a oziębłością. Doskonale dostrzegli to choćby Platon i Nietzsche. Ten ostatni sądził wręcz, że „[w]ielkość charakteru nie polega na tem, że się afektów nie posiada - przeciwnie, posiada się je w stopniu najstraszliwszym; lecz się je na cuglach prowadzi" (Nietzsche, 2006, s. 309). Bardziej radykalnie wyraził to Mistrz Eckhart: „Musisz wiedzieć, że skłonność do złego prawemu człowiekowi przynosi niemałe i błogosławione owoce" (Eckhart, 2001, s. 39). Człowiek osiąga wolność od namiętności (apatheia) i niezłomność (ataraxia) wówczas, gdy żyje w świadomej i dobrowolnej zgodzie ze swym losem. To nasze projekcje sprawiają, że dane zdarzenia wprowadzają nas w stan pomieszania i sprawiają nam ból lub radość. Wyobrażenia, które mamy na temat zdarzeń, a nie one same stają się przyczynami naszych cierpień.

By nie popadać w żaden rodzaj zniewolenia duchowego warto pójść za wyzwalającą od uwikłań, o ile głębiej się nad nią zastanowimy, wskazówką Epikteta:

Gdyby tak ktoś twe ciało oddał pod władzę pierwszego lepszego napotkanego człowieka, jakże bardzo byś wrzał z wściekłości! No, ale kiedy ty sam własną swą duszę oddajesz pod władzę pierwszego lepszego, tak iż dusza ta wpada w niepokój i zamęt, kiedy on z ciebie szydzi, to czyż nie powinieneś się wstydzić z tego powodu? (Epiktet, 1961, s. 469).

Człowiek wolny, w mniemaniu stoickich wychowawców (i jak najbardziej moim), to osoba wolna od przywiązań, ale nie wykorzeniona. Wydaje mi się, że cała sztuka życia polega na próbie dynamicznego godzenia z sobą wolności od przywiązań, która nie podcina naszych korzeni, a byciem częścią danej kultury, ale nie poprzez wewnętrzne przymusy, które rodzą frustrację i zło oraz wikłają nas w obłędną pułapkę akceptacji czegoś i reakcji na coś. Rację miał Ignacy Loyola, kiedy nauczał, że chcąc zrzucić z siebie przywiązanie, powinniśmy je zrzucić w taki sposób, aby nie mieć przywiązania ani do 
zatrzymania tego, do czego jesteśmy przywiązani, ani do utracenia tego (zob. Loyola, 2002, s. 99).

Ku wolności zmierzamy oczywiście nie wtedy, kiedy dążymy ku wyobrażonemu stanowi idealnemu, branemu za widmo wolności, lecz wówczas, kiedy zaczynamy uświadamiać istotę tego, co niewoli. Wolność jest zatem nie-zniewoleniem, negacją niewoli. Wielką zasługą Freuda jest spostrzeżenie, że pewne właściwości, które są pozytywnym objawem w fazach rozwojowych okresu dzieciństwa i adolescencji, stają się patologiczne w przypadku człowieka dorosłego. Zupełnie inaczej będziemy oceniać czepiającego się matczynej spódnicy trzylatka, a czyniącego to samo (co jest coraz częstsze) trzydziestolatka. Będąc ludźmi dorosłymi, wolnymi i w miarę samoświadomymi fundujemy sobie zniewolenia, kiedy przywiązujemy się chorobliwie do osób: matki, ojca, żony, dzieci, rodzeństwa, przyjaciół, znajomych (krąg rodzinny i krąg towarzyski); do dóbr materialnych (przedmioty materialne, posiadłości, pieniądz sam w sobie i jako potencjalny środek nabywczy); do rang i zaszczytów (uznanie, aprobata, szacunek, nagrody, tytuły naukowe, zawodowe, oficerskie, przywileje etc.); do idei, opinii i sądów (przekonania, czyli nasze introjekcje, projekcje i racjonalizacje); do substancji zmieniających nastrój (narkotyki, leki przeciwdepresyjne i inne „cudowne” mikstury); do ćwiczeń fizycznych, ascetycznych, medytacji; do obrazu siebie (mniej lub bardziej odszczepionego od tego, jacy naprawdę jesteśmy); do cielesności (bardziej lub mniej zatrzymanej w czasie, wbrew zegarowi biologicznemu, najlepiej przypadającym na dojrzewanie płciowe i fazę wczesnej dorosłości). Dramatem jest to, że daliśmy się oszukać i wciąż się oszukujemy, że przywiązanie jest oznaką zdrowia psychicznego. Nieraz przedstawia się nam jako ideały osoby zależne od opinii społecznej, od zaszczytów i uznania społecznego. Dzieje się tak dlatego, że przywykliśmy sądzić, iż wyzwalając się od przywiązania od razu zmierzamy na przeciwległy biegun - ku alienacji, depresji, izolacji od świata i ludzi, ku niezdolności do przejawiania uczuć i patologicznej bezwrażliwości. Tymczasem dokładnie pośrodku, pomiędzy przywiązaniem a bezwrażliwością znajduje się to, co najważniejsze - zdrowy dystans do osób, zdarzeń i rzeczy.

\section{Imagopaci i świat logorei}

Rzeczywistość psychiczna jest w zasadzie jedyną rzeczywistością, której możemy doświadczyć bezpośrednio. To sprawia, że żyjąc w swoim subiektywnym świecie poszukujemy tego, co wspólne w przeżyciach własnych i swych bliźnich, nadając tym wspólnym doświadczeniom pozory realności. Jednak jeśli nawet będziemy próbować podążyć ścieżką wskazaną przez mędrców 
stoickich, musimy zmierzyć się z czymś, co jeszcze do niedawna nie istniało, ze światem stojącym poza jawą a snem, tak charakterystycznym dla ponowoczesności. Chodzi o to, że rzeczywistość została zastąpiona przez obrazy cieni przesuwających się po większych i mniejszych ekranach. Na rozświetlonej ideologią, uwspółcześnionej platońskiej ścianie przesuwają się „poprawieni” nasi bliźni, nasze rodziny, my sami jako ciała androidów z wgranym programem na szczęście, którym próbujemy zastąpić duszę. Nie są to ani twory realne, ani też wytwory naszej żywej wyobraźni. Obrazy „ja” zostały wyprodukowane gdzieś na zewnątrz. Wchodzimy w nie i w role $\mathrm{z}$ nimi związane, niczym w przygotowane dla nas przez anonimowych władców uniformy. W psychopatologii terminem logorea (od 'logos' - słowo i 'rhoà' rzeka) określa się patologicznie szybkie i bezwładne wypowiadanie się, słowotok. Polski antropolog i kulturoznawca Wojciech J. Burszta tymczasem pokazuje nam, że żyjemy w kulturowej, medialnej logorei. Logorea „[t]o mieszanina słowoobrazów z metakomentarzami bez granic" (Burszta, 2015, s. 33).

Słowoobrazy zawłaszczają nasze wyobrażenia przeszłości, teraźniejszości i możliwej przyszłości. Poddając refleksji pracę, konsumpcję, czas wolny i przemysł turystyczny, Burszta wplata w to fascynujące, krótkie rozważanie na temat idei miejsca. W tym celu przywołuje greckie terminy: topos (miejsce abstrakcyjne, jakiś konkretny punkt na mapie) i, rzadziej dzisiaj używane, skazane na zapomnienie, chora („miejsce egzystencjalne, ze wszystkimi cechami czyniącymi go wyjątkowym") (Burszta, 2015, s. 134). To

chora sprawia, że żyjący tam ludzie są innymi, niż byliby w innych miejscach. Jest równocześnie tak, że ludzie żyjący w chora także nań wpływają, zmieniają ją, odciskają na niej swoje piętno. [...] Rezultat tej nieustającej interakcji starożytni zwykli zwać 'poezją świata', do którego warto było docierać (Burszta, 2015, s. 134).

Burszta uświadamia nam, że współczesny człowiek jest obojętny na specyfikę miejsc i widzi tylko abstrakcyjne przestrzenie, czemu oczywiście sprzyja nowoczesna wizja świata rozczłonkowanego, stworzonego $z$ bezwładnych, niepowiązanych z sobą elementów. Dlatego można rzec za autorem, że „[p]oezja świata skamieniała” (Burszta, 2015, s. 135).

Kiedy pewnego dnia wymieniałem poglądy z psychiatrą i jungistą, Zenonem Waldemarem Dudkiem, na temat fenomenów psychicznych, charakterystycznych dla kultury współczesnej, wykluł się termin ,imagopatia”. Jaka jest różnica pomiędzy imagopatią a logoreą? Imagopatia jest stanem, w którym rzeczywistość wirtualnych „gadających” obrazów staje się jedyną rzeczywistością, jakiej doświadcza podmiot, deprecjonując to, co istnieje poza ekranem. Tym samym to, co zawsze było traktowane jako realne, zostaje zdegra- 
dowane do statusu rzeczy odrealnionych (rodzina, natura, przestrzeń mieszkalna, materialne dziedzictwo kulturowe etc.).

Z. W. Dudek w artykule Syndrom matki pochŁaniająCEj (zob. Dudek, 2003) ukazał sugestywnie bardzo istotny fenomen, jakim jest brak u jednostki wewnętrznej lokalizacji poczucia bezpieczeństwa. Do opisania skutków tego braku autor posłużył się piramidą potrzeb Maslowa. Zdaniem Dudka frustracja potrzeby bezpieczeństwa jest kompensowana przez nadmierną koncentrację ja na pozostałych potrzebach. Wówczas to jednostka redukuje lęk poprzez stawanie się niewolnikiem własnego ciała i popędów, społeczeństwa czy też własnych ambicji i idealnych wyobrażeń o sobie. Świadomość braku wewnętrznego źródła poczucia bezpieczeństwa łączona jest w psychologii głębi z nierozwiązanym problemem separacji ego dziecka od matki. Jednostka dotknięta tym brakiem posiada obniżoną zdolność tolerancji na napięcia, stresy, frustracje i lęki. Z tego powodu miota się pomiędzy uleganiem w sposób niepohamowany pragnieniom, co doprowadza do zabójczej zachłanności, a niemożnością pragnienia, która wiedzie ku apatii, chorobie i rozpaczy.

Poprzez syndrom matki pochłaniającej możemy zaobserwować skutki alienacji od pozytywnych sił macierzyńskich. Przewagę wówczas zyskuje „ciemna moc” natury, która więzi, truje, ogranicza, uniformizuje i pożera. Jednostka ulegająca tej mocy będzie rzutowała na rzeczywistość atrybuty poszukiwanego obiektu macierzyńskiego, ewentualnie zmagała się $\mathrm{z}$ obrazem matki zagrażającej. Tym samym będzie próbowała załatać ten brak poprzez nadmierne przecenianie innych osób czy też przydawanie nadmiernej wartości pełnionym rolom społecznym. Jej zachowanie wynika zatem z próby wyparcia prawdy o sobie, która wiąże się z brakiem poczucia własnej wartości i zaufaniem co do własnych możliwości. Jednak w XXI wieku, wraz z rozkwitem elektronicznych mediów i internetu, sytuacja ulega daleko idącym zmianom. Mianowicie dziecko nie tylko mierzy się z poczuciem bycia kochanym czy niekochanym, rozpieszczanym czy mechanicznie pielęgnowanym przez „zimną, schizoidalną” matkę. Dziecko od najmłodszych lat otrzymuje komunikat, że jego matka bardziej kocha obraz. To, co pojawia się na zminiaturyzowanych ekranach jest prawdziwym obiektem troski nie tak małej rzeszy współczesnych matek. Ich realnym dzieckiem są słowoobrazy, papka wszelkich wizualnych i dźwiękowych fragmentów, zlewająca się z papką znajomych z portali internetowych, zaś dziecko biologiczne staje się tylko, być może, mniej realnym dodatkiem. Można rzec, że mamy do czynienia już nie tylko z matką pochłaniającą, lecz z matką pochłoniętą. Psyche matki pochłoniętej przez świat logorei sprawia, że jej ciało jest jakby 
pozbawione oczu. A niegdyś mówiło się, że patrząc komuś głęboko w oczy, można dostrzec jego duszę. W oczach matek pochłoniętych przez świat obrazów błysk manii przechodzi we wściekłość i osłupienie. W ekran spogląda matka pełna pasji, na dziecko - mityczna Meduza, której pragnieniem jest, by świat poza ekranowymi słowoobrazami skamieniał. Zanim dziecko nauczy się chodzić, będą go zabawiać i kołysać do snu kolorowe wizje zaklęte w ramy tabletów bądź smartfonów. Całe szczęście, że niektóre z tych dzieci przebudzą się i odkryją piękno tego, co przez ich przodków zostało niegdyś odkryte i doświadczone. Być może zostaną one uznane za zaburzone, na powrót ściągane w głąb jaskini cieni i poddane zintensyfikowanemu, psychofarmakologicznemu "praniu mózgu”. Będą musiały podjąć walkę o humanizm i ludzką godność, stawiając się poza nadzieją i beznadzieją. W przeciwnym razie wyruszą wraz z innymi na poszukiwanie matczynych substytutów w świecie labiryntu słowoobrazów, poddani manipulacjom przez nieprzyzwoicie bogacącą się garstkę globalnych oligarchów, żyjących w zupełnie innych przestrzeniach. Tym jest imagopatia: jest to stan, w którym najbardziej realne stają się bóle i rozkosze zadawane przez świat wirtualnych obrazów. Jednak rozkosz nie ulega takiej intensyfikacji jak ból, którego doświadcza się za pośrednictwem świata wirtualnego, ponieważ ból ten wynika $\mathrm{z}$ uświadamiania sobie własnego wybrakowania. Paradoksalnie, jednostka taka żywi iluzje, że w łatwy sposób to wybrakowanie zapełni, wystarczy tylko coś kupić, zrobić to, co czyni zapośredniczony autorytet, a nawet że w jednej chwili przemianie ulegnie na piękną powłokę idola, własne, szpetne ciało. Jednostka ta zaczyna roić sobie, że siłą woli zapanuje nad układem wegetatywnym, erekcją, pobudzeniem seksualnym, orgazmem, pozbędzie się w okamgnieniu lęków i zahamowań, i tego wszystkiego, czego w sobie nie znosi, a nawet wierzy, że siłą woli jest w stanie panować nad tym, co myślą inni. Wychodzę po pieczywo do osiedlowego sklepu, mijam młodą matkę prowadzącą wózek, z głębi którego słychać żałosne popiskiwanie. Matka jest, ale bardziej jej nie ma. Opuszczona głowa, oczy łapczywie spoglądające w hipnotyzujący ekran smartfona. Spaceruje z wirtualnymi cieniami znajomych na Facebooku. Inna matka na placu zabaw porusza huśtawką, na której znajduje się jej kilkuletnie dziecko. Jej też nie ma; opuszczona głowa i wzrok utkwiony w ekranie. Dziecko, gdy wróci do domu, być może dostanie do zabawy stary smartfon rodzica, by nie przeszkadzało, by zostało wchłonięte w ten inny, a jakże bliski świat.

Projekcja jest w psychologii głębi jednym $\mathrm{z}$ najbardziej istotnych mechanizmów obronnych, który wiąże się z rzutowaniem wewnętrznych stanów i wyobrażeń z nieświadomości na otoczenie. Sam w sobie ten mechanizm może być normalny, patologiczny, może też stanowić obronę przed lękiem, jed- 
nak generalnie zubaża osobowość, czyniąc ze świadomości jednostki wąską smugę światła, zagrożoną przez mroczną potęgę nieświadomego. W prymitywnym, archaicznym stadium asymilacji projekcji, wyróżnionym przez uczennicę Junga - Marie-Louise von Franz (zob. Dudek, 2002; Samuels, Shorter, Plaut, 1994) obrazy wyobraźni i marzeń sennych są traktowane jak rzeczywiste. Jednostka żywi mniemanie, że to, co widzi w innej osobie, rzeczywiście takie jest. Następuje przemieszanie porządku wewnętrznego z porządkiem zewnętrznym. U zdrowego człowieka poczucie to występuje właściwie tylko w snach, zaś w chorobach psychicznych emocje nie tylko są doznaniami wewnętrznymi i subiektywnymi, lecz stają się faktami. U imagopatów mamy do czynienia $\mathrm{z}$ uwięzieniem psyche na dobre i na złe $\mathrm{w}$ stadium archaicznym, z tym że zamiast obrazów wyobraźni i marzeń sennych, rzeczywiste stają się obrazy odbierane i konsumowane za pośrednictwem monitorów. Imagopata wierzy w tożsamość osobowości producenta treści z „osobowością” produktu, włącznie z ludzkimi postaciami, które zabawiają, pouczają, próbują straszyć, podniecać, namawiać na konsumpcję, relaks, ćwiczenia fizyczne etc. Również dotyczy to znajomych z portali społecznościowych, których słowotok myśli, opinii, deklaracji, ocen traktowany bywa jako nieodłącznie związany z charakterem autorów, jak i z prawdą na nasz temat, która przecież może być tylko chwilowym kaprysem któregoś z konsumujących wrażenia innych imagopatów. Niepostrzeżenie projekcja może przejść w introjekcję. Rzutując na obraz nieuświadamiane przez siebie własne możliwości imagopata wchłania następnie te właściwości na powrót, tylko że zdeformowane, spotęgowane i zestandaryzowane. Uzyskuje w ten sposób „szczęście” bycia nienasyconym konsumentem i odnawiającym się każdego dnia produktem konsumenckim. Nabywa na przykład zestaw: smartfona ze statywem do selfie.

Mianem „ekshibicjonizmu” określa się parafilię seksualną, która charakteryzuje się tym, że osobnik osiąga satysfakcję seksualną poprzez demonstrowanie obnażonych własnych narządów płciowych. Podniecenie wzmaga się, gdy świadek zdarzenia doświadcza lęku i szoku. Zazwyczaj obnażającym się jest mężczyzna, ofiarą - kobieta. U płci pięknej ekshibicjonizm jest rzadkością, aczkolwiek Antoni Kępiński (1988) zwrócił uwagę na eksponowanie przez kobiety własnego ciała, które odbywało się (kilka dekad temu) w granicach ustalonych kulturowo norm. Ekshibicjonistą potocznie nazywamy również kogoś, kto zbytnio się uzewnętrznia, zarzuca wręcz innych informacjami na temat swoich najbardziej intymnych spraw. Obłędna moda na fotografię autoportretową, nazywaną selfie, którą obserwujemy w ostatnich latach wraz z rozkwitem mediów społecznościowych (Facebook, Twitter, Instagram), nie powinna być zaskoczeniem dla kogoś, kto interesuje się kulturą współczesną. 
Narcystyczna osobowość naszych czasów przepoczwarzyła się w osobowości depresyjne, maniakalne, dwubiegunowe. Zaskoczeniem natomiast jest to, że jednostki dla wspaniałego, szokującego i ekscytującego ujęcia są w stanie poświęcić swoje życie. Maski z fotografii typu selfie są dość często tak radosne, że radość ta objawia to, co pragnęło się ukryć: głęboki smutek i beznadzieję, które zagłusza się zabawą, używkami, farmakologią i wiarą w propagandę postępu. Rolę maski nie tak rzadko pełnią również poszczególne części ciała (pośladki, uda, stopy, męskie klatki piersiowe, kobiece piersi etc.), obnażone bądź zakryte perwersyjną (także jeśli chodzi o cenę marki) bielizną. Autoportrety, rozmnożone w setki tysięcy i miliony kopii, żyją. A obdarzone życiem, zastygłe i płynne jednocześnie i swym nieokreślonym stanem zatrzymujące czas, na daleki plan spychają oryginał, czującą istotę, która, by poczuć, że żyje, poszukuje coraz bardziej ekstremalnych doznań, doznań na pograniczu życia i śmierci. Perwersyjne opętanie przez Tanatosa, który potrafi podszywać się pod Erosa, uwidacznia się w autopozach nad przepaściami, w objęciach niebezpiecznych substancji i przedmiotów, a nawet drapieżników. W jednej chwili jest się w swej pozie świętym, świętą, by za chwilę stać się dziwką, gangsterem, sutenerem, podróżnikiem, alkoholikiem, obłąkanym bądź mędrcem. Niczym ekshibicjonista eksponujący organ płciowy, entuzjasta selfie zamienia swój portret w gadżet nasączony perwersyjnym erotyzmem. W ujęciu Freuda (1998) Eros i Tanatos są blisko ze sobą powiązane. Zdaniem Terry'ego Eagletona jedna potęga i druga na przykład „oznaczają poddanie się" (Eagleton, 2012, s. 103). Ja atakowane przez nad ja (poczucie winy, wyrzuty sumienia, pragnienie sprostania wymogom ideału), popychane do różnorodnych, nie zawsze akceptowanych przez siebie, aktywności przez to (id; sfera popędowo-emocjonalna), dręczone przez świat zewnętrzny, dąży do własnego zaniku.

Jeśli potraktujemy ja jako zasadę rzeczywistości, która stara się uzyskać stan dynamicznej równowagi między zasadą przyjemności (to) a wymogami ideału kulturowego i sumienia (nad ja), to oczywiście każdy atak na ja będzie podważeniem tego, co uznajemy za rzeczywistość, będzie znoszeniem granic między realnym a wirtualnym, między rzeczywistością a ideologicznym fantazmatem czy rzeczywistością i jej widmem. Moda na selfie stoi poza dobrem i złem. Jest zastępczym spełnieniem odwiecznych pragnień, których nosicielami są bohaterowie i bohaterki baśni i mitów. Mieć cudowną moc przemieniania się w zależności od okoliczności i warunków, metamorfozy, która prowadzi do sukcesu. Z tym że olbrzymia większość doświadcza zarówno sukcesu, jak i porażki, niczym we śnie, który stał się rzeczywistością, mimo że ta niby-rzeczywistość jest dalszym ciągiem snu. Radość z powodu urojonych 
osiągnięć, pochwał i smutek porażki, braku akceptacji, rozstrzelania przez hejty. Droga ku manii i depresji. Z tym że pierwszy z tych stanów jest stanem pożądanym, przed pułapką, którego nie chroni już prawie żadne nadprzyrodzone prawo, żadne hybris. Ale im bardziej ten stan się osiąga, tym bardziej wyłania się przewrotna mądrość Heraklita, którą ten tajemniczy filozof zawarł w słynnej sentencji, że „,[d]roga w górę jest drogą w dół”.

Warto na pewno spojrzeć na fenomen „selfie” przez pryzmat konsumowania intensywnych doznań, gdzie w centrum tego tajfunu znajduje się omnipotentne wyobrażeniowe ja, udające, że jest oto tą powłoką cielesną. Intensywne doznanie przemija, jest ulotne, nieraz kończy się obniżeniem nastroju psychicznego i obdarza chroniczną tęsknotą. Powtórzenie tego stanu nie jest tożsame z przeżyciem z przeszłości, które stało się wspomnieniem. W przypadku „selfie" skonsumowane wrażenie daje iluzoryczną nadzieję na pewność odtworzenia doznania, tym samym jednostka wierzy, że to, co minęło, co można w każdej chwili przywołać, jest idealnym duplikatem. Mniemając, że znajduje się w niebie wiecznych rozkoszy, które zależą od jego woli, entuzjasta selfie zapomina, że jest to niebo buddyjskie, z którego prędzej czy później się spada w coraz niższe światy, a zazwyczaj upadek pogrąża w świecie "głodnych duchów", wciąż nienasyconych, podążających drogą nie życia, lecz popychanych przez autodestruktywną, autonomiczną siłę popędu śmierci, ku nieograniczonej konsumpcji towarów i doznań.

\section{BIBLIOGRAFIA:}

Bartkowski, J. (2008). „Hybris” jako patologia charyzmy. W: J. Sieradzan (red.), Charyzma: jej funkcja w życiu religijnym, politycznym i społecznym (s. 113-131). Białystok: Wydawnictwo Uniwersytetu w Białymstoku.

Burszta, W. J. (2015). Preteksty. Gdańsk: Wydawnictwo Naukowe Katedra.

Dudek, Z. W. (2002). Podstawy psychologii Junga. Od psychologii głębi do psychologii integral$n e j$. Warszawa: ENETEIA.

Dudek, Z. W. (2003). Syndrom matki pochłaniającej. Albo albo. Problemy psychologii i kultury, nr 1.

Eagleton, T. (2012). Zło. Przeł. B. Baran. Warszawa: „Czytelnik”.

Eckhart, J. (2001). Pouczenia duchowe. Wybór traktatów i kazań. Przekł. W. Szymona OP. Poznań: W drodze.

Epiktet. (1961). Diatryby, Encheridion z dodatkiem Fragmentów oraz Gnomologium Epiktetowego. Przekł. L. Joachimowicz. Warszawa: PWN.

Freud, S. (1998). Pisma społeczne. Dzieła. (t. 4). Przekł. A. Ochocki, M. Poręba, R. Reszke. Warszawa: KR.

Grün, A. (1999). Drogi ku wolności. Przekł. K. Zimmerer, Kraków: WAM.

Hadot, P. (2004). Twierdza wewnętrzna. Wprowadzenie do rozmyślań Marka Aureliusza. Przekł. P. Domański. Kęty: WYDAWNICTWO ANTYK.

Kępiński, A. (1988). Z psychopatologii życia seksualnego. Warszawa: PZWL. Loyola, I. (2002). Ćwiczenia duchowne. Przekł. M. Bednarz, Kraków: WAM.

Marek Aureliusz. (2001). Rozmyślania. Przekł. M. Reiter. Warszawa: De Agostini Polska. 
Nietzsche, F. (2006). Wola mocy. Przekł. S. Frycz, K. Drzewiecki. Kraków: Zielona Sowa.

Popowski, R. (1997). Wielki słownik grecko-polski Nowego Testamentu. Warszawa: Oficyna Wydawnicza „Vocatio”.

Samuels, A., Shorter, B., Plaut, F. (1994). Krytyczny słownik analizy jungowskiej. Przekł. W. Bobecki, L. Zielińska. Wałbrzych: Unus.

Sieradzan, J. (2014). Inicjacja w szaleństwo. Albo albo. Problemy psychologii i kultury, z. 1, s. 37-45.

Sloterdijk, P. (2008). Reguły dla ludzkiego zwierzyńca. Odpowiedź na Heideggera list o humanizmie. Przekł. A. Żychliński. Przegląd Kulturoznawczy, nr 4, s. 40-62.

Pandita himi, Sayadaw U. (2004). Jeszcze w tym życiu. Nauki Buddy prowadzace ku wyzwoleniu. Przeł. M. Tarnowski, A. Klegon, B. Bobolik, Z. Molski. Przesieka: Stowarzyszenie Buddyjskie Sangha „Kandzeon”; Wrocław: Patra.

\section{SUMMARY}

\section{Man non-enslaved.}

From the Hellenistic Stoics educators to postmodern orgy of desires

The article is an attempt to juxtapose the ideal of man postulated by Epictetus and Marcus Aurelius with postmodern tyranny of success and manic-narcissistic vision of human nature. The basis for discussion is the standpoint of Peter Sloterdijk, who said that in highly developed cultures, upbringing and education are influenced by inhibitory factors and depriving of the brakes factors. A human being, who frightened in the Hellenistic period, as a violation of "hubris" madman, now functions as imagopathy, a perfect product, living in a world of possibilities and the blurring of the boundaries between the real and the virtual.

KEY WORDS: homo inhumanus, hubris, stoicism, desire, logorea, imagopathy, selfie. 